\title{
Universities' Intellectual Property: Path for Innovation or Patent Competition?
}

\author{
Gustavo Dalmarco', Mariana de Freitas Dewes ${ }^{2}$, Paulo Antonio Zawislak ${ }^{3}$, Antonio Domingos Padula ${ }^{4}$
}

\begin{abstract}
Technological innovation is represented by the conversion of knowledge into new products and processes which, when commercialized, generate wealth. In relations with companies, universities' role is to develop scientific knowledge, fostering industry's R\&D activities. This article proposes an analysis of the technology transfer process performed by public universities in Brazil. Results demonstrate that universities are facing difficulties in requesting and licensing patents based on scientific results, due to lack of commercial contact with companies and their limitations in adapting available technologies. The increase in scientific output is not being effectively transformed into new technologies for products and services, exposing the necessity for new policies to approach university-industry relations. For universities, this may mean rethinking the role of patents in the technology transfer process, such as increasing co-authorship with companies and have companies support technological research within the university, instead of investing in legal protection, distant from market needs.
\end{abstract}

Keywords: University patent; technology transfer office; open innovation.

\footnotetext{
' Universidade Federal do Rio Grande do Sul - UFRGS - Programa de Pós-Graduação em Administração. Address: Rua Washington Luiz, 855. Centro - Porto Alegre- RS - Brazil CEP: 90.010-460 - Phone: +55 5133083728 / Fax: +55 513308 399I- E-mail: gdalmarco@ea.ufrgs.br ${ }^{2}$ Universidade Federal do Rio Grande do Sul - UFRGS- Programa de Pós-Graduação em Administração.Address: Rua Washington Luiz, 855. Centro - Porto Alegre- RS - Brazil CEP: 90.010-460 - Phone: +55 5I 33083728 / Fax: +55 5I 3308 399I- E-mail: mfdewes@ea.ufrgs.br ${ }^{3}$ Universidade Federal do Rio Grande do Sul - UFRGS - Programa de Pós-Graduação em Administração. Address: Rua Washington Luiz, 855. Centro - Porto Alegre- RS - Brazil CEP: 90.010-460 - Phone: +55 5133083728 / Fax: +55 5 I 3308 399I- E-mail:paz@ea.ufrgs.br ${ }^{4}$ Universidade Federal do Rio Grande do Sul - UFRGS - Programa de Pós-Graduação em Administração. Address: Rua Washington Luiz, 855. Centro - Porto Alegre- RS - Brazil CEP: 90.0 I0-460 - Phone: +55 5 I 33083728 / Fax:+55 5 I 3308 399I- E-mail:adpadula@ea.ufrgs.br
} 


\section{Introduction}

It is common sense that technological innovation is one of the key drivers of socio-economic development. It occurs mainly when firms create, through research and development (R\&D), new products or processes (Winter, 1988). But, in order for a firm to gain advantage over competitors, technological advances should happen at the knowledge frontier, originating from state of the art scientific and technological research (Dosi, 1988).

The process of approaching scientific results to technology development is known, among other definitions, as university-industry relations. Until the 1990s, large companies conducted basic and applied research, developing technological innovations in an autonomous process (Nelson \& Rosenberg, 1993). Lately, however, with increasing complexity and costs of developing state of the art technologies, large firms are focusing more on applied research, leaving basic research for institutions such as universities and research centres (Auerswald, Branscomb, Demos and Min, 2005).

In order to improve this kind of relation, many theories describe not only knowledge transfer among institutions, but also the importance of government in stimulating this kind of partnership (Etzkowitz, 200I; Chesbrough, 2006). The role of universities in the innovation process is to create and develop new knowledge. Yet government is also an important actor. Depending on government policies, universities may create joint-ventures with firms (Eun, Lee and Wu, 2006), encourage companies to hire graduate students to conduct R\&D projects (Tödtling, Lehner and Kaufmann, 2009), or create an environment which attracts new technology based start-up companies (Etzkowitz, Mello and Almeida, 2005). These three kinds of institutions involved in the innovation process may develop different roles according to each country.

When describing the innovation process in Brazil, universities seem to be evolving as knowledge creators. This can be observed by the increase in the number of scientific publications (from 19,436 in 2007 to 32,100 in 2009, being classified as the 13th country in articles published in 2009) (MCT, 20l0). In order to transfer the created knowledge to companies, universities are establishing Technology Transfer Offices (TTO), which are responsible for seeking market opportunities, filing patents and managing contracts between companies and the university.
Despite important growth in the number of published articles, it seems that in general TTOs are having difficulties to approach industry needs (Siegel, Waldman, Atwater and Link, 2003; Anderson, Daim, Lavoie, 2007). In Brazil, universities are concerned with filing patents related to scientific results (Amadei \& Torkomian, 2009), without knowing if a company may be interested in them. Brazil is facing a technological problem, as just a small number of national companies launch innovative products (IBGE, 20I0). Adding this to the lack of planning by TTOs, the innovation cycle proposed by Etzkowitz (200I) and many other authors may not be accomplished.

Considering the scenario described above, this article proposes an analysis of the technology transfer process performed by the largest universities in Brazil. The selected universities are traditionally research universities, offering a large number of graduate courses. This article aims to add to other studies conducted among Brazilian universities (Garnica \& Torkomian, 2009; Oliveira \& Velho, 2009; Póvoa, 2010; Querido, Lage and Vasconcellos, 20II), focusing on the real innovative effort i.e. patent licensing. There seems to be an effort undertaken by these universities to file as many patents as they can, claiming to be innovative. But, as a matter of fact, many patents are filed without proper market evaluation, resulting in useless intellectual property. Our objective is to evaluate the efficiency of universities' patent licensing, arguing that maybe a patent run is not the right answer to an innovation demand. The research was conducted in seven Brazilian universities with the largest number of graduate courses.

In the next section we describe a background of the role of universities in the innovation process, followed by a description of the activities of universities' TTOs. Section four presents a review of the university structure in Brazil, and section five presents the research method. Section six presents the achieved results, with concluding remarks in section seven. 


\section{Universities and Technological Innovation}

Knowledge is equal to relevant and useful information, based, at least partially, on a real experience (Leonard \& Sensiper, 1998). In order to improve knowledge, scientific experiments and applied experiences are performed complementarily, creating technologies (Nelson, 1959; Marglin, 1990). Generally, technology emerges from man's necessity to overcome barriers, as the lack of strength, precision or even more knowledge (Zawislak, 1995).

In an effort to produce state-of-the-art products, the creation of new knowledge can lead to the creation of new firms, which is the embryo of the innovation process. This process is complete only when the innovative product is commercialized, generating wealth (Jacobides \& Winter, 2003).

This is the main purpose of university-industry relations: to create new innovative firms, based on products originated from state-of-the-art scientific knowledge. But this kind of relationship is not restricted to universities and industries. The university-industry process is related to the approach of entities responsible for creating scientific knowledge (universities, public and private research institutions, etc) with entities responsible for the economic application of knowledge (industries, start-up firms, etc.) (Nelson, 1959; Dosi, 1988; Mowery \& Rosenberg, 1989).

There are a few university-industry relations-based theories. Sabato's triangle describes three fundamental actors to support research activities based on technological innovation, boosting economic development: Government, Industry and Scientific-Technological Infrastructure (Sabato \& Botana, 1975).

In an updated view of Sabato's triangle, the Triple Helix from Etzkowitz (2003) also integrates science, technology and economic development among the same three actors: government, industry and university. But Etzkowitz's model is based on a helix, where knowledge flows mainly between industry and scientific actors, whereas government remains in a position of policy development and monitoring. Etzkowitz (200l) also describes the new behaviour of universities, which following the second academic revolution is developing research closer to industry and market needs as an effort to reduce the gap between academia and companies.
Considering the open innovation approach, the whole process relies predominantly on knowledge relationships, including between universities and industries, than on governmental support. Here companies participate in a wide range of partnerships, receiving and transmitting knowledge to many players such as research centres and other companies (Chesbrough, 2006; Chesbrough \& Crowther, 2006; Perkmann \& Walsh, 2007; Spithoven, Clarysse and Knockaert, 2010).

Based on the Triple Helix and Open Innovation concepts, Brazilian universities are investing in scientific production and intellectual property. As research centres and universities are described as knowledge creators, efforts are being made in order to transfer created knowledge to companies. In order to approach scientific research to companies' needs, universities and research centres have established technology transfer offices.

\section{TTO Background}

In order to transfer knowledge to companies, universities are establishing technology transfer offices (TTO), which are responsible for seeking market opportunities, filing patents and managing contracts between companies and the university. In terms of organizational structure, according to Macho-Stadler, Pérez-Castrillo and Veugelers (2007), creating a specialized TTO within a university can be instrumental in developing relations with an industry. A dedicated transfer unit allows for specialization in support services, notably, partner search, management of intellectual property, and business development. In addition, Hellmann (2007) describes patenting as a complement of doing research, as it facilitates the delegation of activities to TTOs.

TTOs work as an "intermediary" between technology suppliers (university scientists) and those who can potentially commercialize them, i.e. firms, entrepreneurs, and venture capitalists. TTOs facilitate commercial knowledge transfer of intellectual property resulting from university research through licensing to existing firms or start-up companies of inventions or other forms (Siegel, Veugelers and Wright, 2007). According to these authors, the activities of TTOs have important economic and policy implications, since licensing agreements and universitybased start-ups can result in additional revenue for the 
university, employment opportunities for university-based researchers (especially postdocs) and graduate students, and local economic and technological spillovers through the stimulation of additional R\&D investment and job creation.

However, there has been little systematic understanding of organizational practices in management of university intellectual property, despite the potential importance of university-industry technology transfer as a source of financial gain and economic growth to universities and firms (Siegel et al., 2003; Siegel, Waldman, Atwater and Link, 2004). Adding to this, Anderson et al. (2007) and Thursby and Thursby (2007) found evidences of reduced efficiency of TTOs (47 out of 54 universities researched were described as "inefficient"), when comparing expenses in research to patents filed and incomes from licensing, among other outputs. Also the effect of patent litigation affects TTO's performance, as they need to disrupt their activities in licensing and marketing technologies (Shane \& Somaya, 2007). Bray and Lee (2000) also found that taking equity in start-up firms generated revenues ten times higher than licensing patents. This short review represents one of the main criticisms to the entrepreneur university: are patenting revenues worthwhile or should universities consider another way to receive investments from companies?

Legislation such as the Bayh-Dole Act in the United States led many universities to establish technology transfer offices to manage and protect their intellectual property since the 1980s (Mowery, Sampat and Ziedonis, 2002). This trend has been followed in Brazil, having the Innovation Law been passed at the end of 2004, leading most of the 26 States to adopt similar laws since then (Brasil, 2004).

In Brazil, although the creation of this mechanism represents legal and institutional recognition to incorporate the function of technology transfer, introduction of these new routines in the academic environment has not been fully accepted, due to different perceptions from the university community about the university's mission. While universities and researchers are concerned about developing research which may be patentable, protecting knowledge which could be of interest to companies, TTOs are not prepared to license such patents (Amadei \& Torkomian, 2009). In the end, companies see universities as much more concerned with patenting knowledge, charging a lot for licenses, instead of stimulating the innovation in companies (Lemley, 2007). As described by Querido, Lage and Vasconcellos (201I), a patent is only valid (i.e. innovative) when its technology is used by companies to obtain advantage over competitors.

\section{Creation of Brazilian Research Universities}

The creation of research universities in Brazil began in the second half of the twentieth century. However, it was only by the year 2000 that major changes were introduced to improve academic research in the country.

Consequently, an increase in the number of scientific publicationsmaybeobserved, andBrazil'ssharein theworld's scientific production has reached an average of $2 \%$. In some areas such as agricultural sciences participation is larger than 5\%. Among BRIC countries (Brazil, Russia, India, and China), Brazilian science impact ranks highest (King, 2009).

However, when it comes to patenting results of scientific development, the numbers show a different situation. Between 2000 and 2007, there has been significant growth in the number of patents filed in Brazil. In spite of this growth, participation of Brazilian universities as users of the intellectual property system is incipient, incomparable to North American universities, for example, which are users of a much more consolidated intellectual property protection system (Oliveira \& Velho, 2009).

Emphasis goes to universities in Brazil's Southeast region, (mainly those in the State of São Paulo), responsible for 1,699 or $79.5 \%$ of the patents filed by Brazilian universities between 1979 and 2007. This is explained by the concentration of researchers, public investments, and scientific and technological institutions in this region. The South region (comprising the states of Rio Grande do Sul, Santa Catarina, and Paraná) is second in this ranking, with 259 (I2.3\%) filed patents (Oliveira \& Velho, 2009).

Three changes occurred during the 1990s were among the main causes of the increase in university patents in this period. First, a fact that led to radical changes in the Brazilian legal framework related to intellectual property was the country's entrance in the World Trade Organization, thus acceding to TRIPS (Trade-Related Aspects of Intellectual Property Rights) agreement in 1995; second, increase in the intensity of academic research activity, translated by increase in investments in graduate studies, and also by growth in the number of researchers involved in academic research activity as a result of more 
PhDs trained annually; and third, change of academic researchers' behaviour toward intellectual property rights, motivated by the creation of technology transfer offices in universities, and by updates of general rules which define researcher participation in the economic results obtained by research commercialization.

As a matter of fact, starting in the 1990s, a set of structural, legal, financial, and human aspects seems to have changed the context involving academia, creating a more favourable environment for protection and commercialization of academic research (Póvoa, 2010).

However, after more than a decade having passed with these changes in place, we feel that patenting activity by universities in Brazil should be studied in view of its effective results for innovation.

\section{Research Method}

The method employed in this research was a multiple case study. This method is adequate when it is necessary to investigate an event in its real context (Yin, 2003). The questionnaire comprised ten open questions, comprising matters related to respondents' opinions and data related to university, such as the number of patents and students.

Two questions were proposed to identify the main difficulties that a TTO faces on a daily basis, considering that the TTO process is still incipient in Brazilian universities. Adding to this, quantitative questions aimed to measure the number of patents created and licensed by the university, evaluating the performance of the whole process.

Questionnaires were sent by e-mail to TTOs of ten universities in Brazil with the largest number of graduate courses. Universities which did not answer the e-mail were later contacted by phone. In the end we had a response rate of $70 \%$. All respondents were public universities, which receive mainly public funding and represent most of the Brazilian qualified research outcomes. All questionnaires were answered in Portuguese, and afterwards translated to English by the authors.

\section{Results}

In spite of difficulties, Brazilian universities are making an effort to protect their main research outcomes. Although only seven respondents answered our request, some evidences can be observed from the data. As it can be seen in table 0I, almost all universities have had an established TTO office for more than ten years. This means that even more scientific research is being considered as a way to stimulate technological innovation, and universities see licensing activities as a way of supporting research. 


\begin{tabular}{|l|c|c|c|c|c|c|c|}
\hline \multicolumn{1}{|c|}{ University } & A & B & C & D & E & F & G \\
\hline $\begin{array}{l}\text { Undergraduate } \\
\text { students }\end{array}$ & 38038 & 32630 & 24552 & 28000 & 56998 & 28884 & 36000 \\
\hline $\begin{array}{l}\text { Graduate } \\
\text { courses }\end{array}$ & 144 & 115 & 125 & 114 & 291 & 124 & 174 \\
\hline $\begin{array}{l}\text { Graduate } \\
\text { students }\end{array}$ & 12862 & 13861 & 12927 & 6210 & 25591 & 6381 & 10000 \\
\hline $\begin{array}{l}\text { Y ear of TT0 } \\
\text { establishment }\end{array}$ & 1997 & 1984 & 1997 & 2003 & 2003 & 1999 & 2001 \\
\hline $\begin{array}{l}\text { Number of } \\
\text { TTO staff }\end{array}$ & 14 & 37 & 35 & 13 & 57 & 11 & 20 \\
\hline
\end{tabular}

Table 0I - University numbers

No relation was found between the number of graduate courses and the number of TTO staff. Besides the university with the most graduate courses having more TTO staff (university E, 29l graduate courses and 57 people located at the TTO), the others do not follow the same rule. As it can be seen, the second university, G, with 174 courses, has 20 employees in its TTO, while the third (university A, 144 courses) has 14 employees, and the fourth (university C, with 125 courses) has 35 employees working at the TTO. Unfortunately we did not have access to data related to the scientific output (publications) of the universities here described, but this could be an explanation for the discrepancy between graduate courses and TTO staff. It could be that the scientific output of those universities demanded a bigger staff to analyze such demand.
As can be observed in table 02, universities B, C and $\mathrm{E}$ have most patent applications. Although the oldest TTO presents the highest number of patent applications (university B), the second in number of patents has one of the youngest TTOs established (university E). 


\begin{tabular}{|c|c|c|c|c|c|c|c|}
\hline U niversity & A & B & C & D & $E$ & $F$ & G \\
\hline $\begin{array}{l}\text { Patent } \\
\text { applications }\end{array}$ & 122 & 626 & 362 & 67 & 571 & 64 & 291 \\
\hline Patents & 4 & 66 & 16 & 0 & $?$ & 13 & 7 \\
\hline $\begin{array}{l}\text { Patents co- } \\
\text { authored with } \\
\text { companies }\end{array}$ & 38 & $\begin{array}{c}\mathrm{N} \text { ot } \\
\text { informed }\end{array}$ & 29 & 01 & $\begin{array}{c}\mathrm{N} \text { ot } \\
\text { informed }\end{array}$ & 08 & $\begin{array}{c}\text { Not } \\
\text { informed }\end{array}$ \\
\hline $\begin{array}{l}\text { Licensed } \\
\text { patents }\end{array}$ & 15 & 123 & 57 & 01 & 23 & 2 & 4 \\
\hline
\end{tabular}

Table 02 - Patent data from universities

Regarding the number of patent applications, it does not follow the number of graduate courses, or the year of establishment of the TTO. Different from what suggested Póvoa (2008), in the present research we were unable to establish any relation between the number of students and the number of patent applications.

Considering the innovative effort, we described the participation of companies in co-authoring patents. Here it can be observed that all universities (except B, E and G) have patents co-authored with companies. Among them, university $A$ has the biggest share of patents with company co-authorship (about $30 \%$ of the total number of its patents), followed by university $F$ with $13 \%$ and university $C$ with $8 \%$. In addition, universities $B$ and $C$ have the highest share of patents licensed $(20 \%$ and $16 \%$ respectively). On the other hand, university $E$, which has the highest amount of patent applications per year of TTO activity, does not follow the same path regarding licenses. It is the fourth in the number of licenses, behind university A (which of its 122 patent applications has licensed 12\%).

Following the quantitative data, two qualitative questions were made regarding universities' patenting and licensing activities. Describing the main difficulties in depositing and licensing patents, all respondents mentioned lack of support from academic inventors as the main difficulty faced when filing a patent. As the inventors must publish their results in scientific journals, some of them do not understand the importance of protecting knowledge before publishing. As described by university $\mathrm{D}$ :

"It is difficult to update researchers with concepts of IP and innovation. Besides, it is hard to find out what researchers are doing, and whether they invented something which could be patented, as sometimes they are not aware of what is commercially viable or not"

On the other hand, the distance between scientific results and commercial application may jeopardize the patent itself, as it is unable to predict all possible applications for the actual technology. A patent which is incorrectly filed may reveal critical details of the invention, instead of protecting it. As mentioned by university A:

"Research results are still far away from commercial applications, and due to the lack of IP expertise from inventors it is difficult to translate the academic result to the commercial world of patents" 
Moreover, TTOs also encounter difficulties in licensing patented technologies, as they usually depend on the inventor to indicate or approach companies that may be interested in the invention. Although the patent may only be granted in five to ten years, the application protects the invention for licensing purposes. But the difficulty in licensing the invention is also related to lack of interest from companies. As described by university F, "companies want technologies which have already been validated and certificated by regulation institutes. They look for technologies which have lower risks". In addition, university E says that "Brazilian companies do not have a R\&D culture", while university $D$ says "When the technology protected by a patent is close to a final product the negotiation flows. When it is raw, it is practically impossible to negotiate".

\section{Concluding Remarks}

The role of universities in the innovative activity of firms has been discussed for a long time, with many different policies having been analyzed and suggested. The BayhDole act (Mowery et al, 2002), in 1980, was the initial breakthrough, allowing North American universities to protect and profit from the knowledge they created. In Brazil, a similar law was approved in 2004 , as mentioned in Section 3, and since then universities are trying to adapt their regulations to stimulate patent filing.

This article proposed an analysis of the innovative effort of Brazilian universities. The increase in published scientific papers should stimulate the creation of new technologies, boosting innovative activity in Brazilian industry. But it seems that universities are much more concerned in protecting the knowledge they create, instead of looking for partnerships with companies. In the end, rather than supplying technologies to companies, universities are keeping knowledge internally in the form of patents.

Preliminary results of this study demonstrate an effort made by some universities in transforming scientific outcomes into patents. Universities B and E have the highest number of patents requested (almost double in number of patents of the third university), but this is not directly related to the number of graduate students, as we initially believed. But this is only one of the factors that may affect patenting activity, as may be concluded from this research. Other universities from the sample have almost the same number of graduate students as $B$ but have requested less than half the number of patents. However, there seems to be misuse in patent filing practices performed by the universities, or a lack of interest from the industry. Interviews conducted with the TTOs show that, besides the necessity of indicating the industrial use of such inventions, they are not being able to reach companies which may be interested in the technologies. As a matter of fact, this activity is being performed by the researchers, who lack expertise in the business area. It is necessary to find a balance between TTOs and researchers, defining each one's role in the licensing process. Researchers should do research, and may advise TTOs regarding companies which may be interested in such technologies.

Universities stated that, in general, TTOs are not prepared to respond to companies' needs. As a consequence, universities may establish weak links with industry, underexploring the potential of the technology it owns. As described by Siegel et al (2004), TTO managers with substantial business experience have a better sense to explore a technology's business opportunity, establishing stronger links with industry. This demonstrates the "lack of professionalism" of such managers, in a way that they don't have the necessary business experience to run a TTO program. As a consequence, some universities end up relying on external partners who commercialise academic technologies.

On the other hand, TTOs believe that companies should be active partners when looking for new technologies. In some cases they are, but instead of contacting TTOs, they go directly to researchers through informal contact or hiring them as consultants. As a consequence of passive behaviour, universities may be missing licensing opportunities, jeopardizing the whole process. It is not only a problem with the TTO staff, but with the whole process. TTOs lack specialized professionals because universities do not invest enough in them, leaving professors to run the business activities almost by themselves. As a consequence, TTOs rely mostly on patent filing, sharing the licensing responsibility with researchers.

The results presented in this article demonstrate what seems to be a misunderstanding of the innovative process. As evidenced in articles published in Brazil (Amadei \& Torkomian, 2009; Oliveira \& Velho, 2009), universities and researchers are mainly interested in patenting inventions, but are still learning, considering technology licensing. Some 
particular cases, as described by Garnica \& Torkomian (2009), describe the efficiency of patent licensing in some Brazilian universities, but in general universities are illprepared to actively transfer technologies to companies. In the end, due to legal restrictions and management immaturity, they act as "Patent Trolls" (Lemley, 2007), owning patents in technologies which should have an open approach to companies.

It is necessary to discuss the patent race which is occurring in the Brazilian scenario, as it is not resulting in advances for companies. One item that well represents this patent race, presented by Amadei \& Torkomian (2009), describes that $80 \%$ of patents from universities in the region of São Paulo were filed with the university as single author. This may well represent that companies are not involved in the research process. In an environment where a small amount of companies develop innovative activities, there should be a bigger participation of companies in research, upgrading their capacity to absorb technologies from universities. Consequently, universities are not able to license patents because companies are not ready to use them.

University-industry relations should be broader than the patenting process. Universities are wrongly trying to sustain themselves based on royalties from patents. As described by many authors (Bray \& Lee, 2000; Anderson et al., 2007; Thursby \& Thursby, 2007; Shane \& Somaya, 2007), licensing is not enough to sustain a TTO staff, monitor illegal use of patents and consequent patent litigation. Universities should mainly be concerned in receiving funds from companies to support scholarships and laboratories, and not royalties. In the end, partnerships can employ students, upgrade companies' knowledge and even result in patents which can pay royalties mainly to researchers, stimulating their activities.

Researchers are expected to develop scientific experiments, which may or may not result in patents. Afterwards, TTO staff should be responsible for promoting and seeking companies interested in further development and commercialization of the technology. The motivation for writing this paper was the growing number of articles published in Brazil which highlight the increase in the number of patents filed by universities, without evaluating if these patents are effectively resulting in innovative activity. A "patent race" seems to be occurring, instead of an "innovation race". Moreover, real efforts should be undertaken on behalf of university TTOs and companies, to effectively boost technological innovations.

\section{References}

AMADEI, J.R.P., Torkomian, A.L.V. (2009) As patentes nas universidades: análise dos depósitos das universidades públicas paulistas. Ci. Inf., Brasília, 38(2), 9-18.

ANDERSON, T.R., Daim, T.U., Lavoie, F.F. (2007). Measuring the efficiency of university technology transfer. Technovation 27(5), 306-318.

AUERSWALD, P., Branscomb, L., Demos, N., Min, B.K. (2005). Understanding private-sector decision making for early-stage technology development: a "between invention and innovation project." Report No. NIST GCR 0284IA. National Institute of Standards and Technology, US Department of Commerce. http://www.atp.nist.gov/eao/ gcr02-84la/gcr02-84la.pdf [Accessed January, 10 2009].

BRASIL, Presidência da República (2004). Lei I0.973, de 2 de Dezembro de 2004.

BRAY, M.J., Lee, J.N. (2000) University Revenues from Technology Transfer: Licensing Fees vs. Equity Positions. Journal of Business Venturing, 15(5-6), 385-392.

CHESBROUGH, H., Crowther, A.K. (2006) Beyond high tech: early adopters of open innovation in other industries. R\&D Management, 36(3), 229-236.

CHESBROUGH, H.W. (2006) Open innovation: a new paradigm for understanding industrial innovation. In Chesbrough, H., Vanhaverbeke, W., West, J. (eds), Open Innovation: Researching a New Paradigm. Oxford: Oxford University Press.

DOSI, G. (1988) The nature of the innovative process. in: Dosi, G., Freeman, C., Nelson, R., Soete, L. (eds.). Technical Change and Economic Theory. London, Pinter.

ETZKOWITZ, H. (200I) The Second Academic Revolution and the Rise of Entrepreneurial Science. IEEE Technology and Society Magazine, 20(2), 18-29.

ETZKOWITZ, H. (2003) Innovation in Innovation: The triple Helix of University-Industry-Government Relations. Social Science Information, 42(3), 293-337. 
ETZKOWITZ, H., Mello, J.M.C., Almeida, M. (2005) Towards "meta-innovation" in Brazil: The evolution of the incubator and the emergence of a triple helix. Research Policy, 34(4), 4II-424.

EUN, J-H., Lee, K., Wu, G. (2006) Explaining the "University-run enterprises" in China: A theoretical framework for university-industry relationship in developing countries and its application to China. Research Policy, 35(9), 1329-1346.

GARNICA, L.A., Torkomian, A.L.V. (2009) Gestão de tecnologia em universidades: uma análise do patenteamento e dos fatores de dificuldade e de apoio à transferência de tecnologia no Estado de São Paulo. Gestão \& Produção, 16(4), 624-638.

HELLMANN, T. (2007) The role of patents for bridging the science to market gap. Journal of Economic Behavior \& Organization. 63(4), 624-647.

IBGE - Brazilian Institute of Geography and Statistics (20l0). Grau de novidade do principal produto e/ou do principal processo nas empresas que implementaram inovações, segundo as atividades das indústrias extrativas e de transformação - Brasil - período 2006-2008. Pesquisa de Inovação Tecnológica 2008. http://www.pintec.ibge.gov. br/downloads/PUBLICACAO/PublicacaoPINTEC2008. pdf [Acessed May, II 20II].

JACOBIDES, M.G., Winter, S.G. (2003) Capabilities, Transaction Costs, and Evolution: Understanding the Institutional Structure of Production. WP 2003-04, Working Paper of the Reginald H. Jones Center. The Wharton School, University of Pennsylvania.

KING, C. (2009) Brazilian Science on the Rise. National Science Indicators. Thomson Reuters. http://sciencewatch. com/ana/fea/09julaugFea/ . [Acessed September, 19 20I0].

LEMLEY, M.A. (2007) Are Universities Patent Trolls? Fordham Intellectual Property, Media \& Entertainment Law Journal, I8(3), 6II-63I.

LEONARD, D., Sensiper, S. (1998) The role of Tacit Knowledge in Group Innovation. California Management Review. 40(3), II2-132.
MACHO-STADLER, I., Pérez-Castrillo, D., Veugelers, R. (2007) Licensing of university inventions: The role of a technology transfer office. International Journal of Industrial Organization, 25(3) 483-5I0.

MARGLIN, S.A. (1990) Loosing touch: the cultural conditions of worker accommodation and resistance. in: Marglin, F.A., Marglin, D. Dominating Knowledge: Development, Culture, and Resistance. Ed. Oxford.

MCT - Ministry of Science and Technology. (2010) Número de artigos brasileiros, da América Latina e do mundo publicados em periódicos científicos indexados pela Thomson/ISI, 198I-2009. http://www.mct.gov.br/index. php/content/view/57/0.html. [Accessed March, 19 2010].

MOWERY, D.C., Rosenberg, N. (1989). Technology and the Pursuit of Economic Growth. Cambridge University Press.

MOWERY, D.C., Sampat, B.N., Ziedonis, A.A. (2002). Learning to patent: institutional experience, learning, and the characteristics ofU.S. University Patents after the BayhDole act, 198I-1992. Management Science 48(I), 73-89.

NELSON, R.R. (1959) The Simple Economics of Basic Scientific Research. The Journal of Political Economy. 67(3), 297-306.

NELSON, R.R., Rosenberg, N. (1993) Technological Innovation and National Systems. In: Nelson, RR. (Ed). National Innovation Systems: a Comparative Study. Oxford Univ. Press, New York.

OLIVEIRA, R. M., Velho, L. M. L. S. (2009) Patentes acadêmicas no Brasil: uma análise sobre as universidades públicas paulistas e seus inventores. Parcerias Estratégicas, CGEE, 14(29), 173-200.

PERKMANN, M., Walsh, K. (2007) University-Industry Relationships and Open Innovation: Towards a Research Agenda. International Journal of Management Reviews. 9(4), 259-280.

PÓVOA, L. M. C. (2008) Patentes de universidades e institutos públicos de pesquisa e a transferência de tecnologia para empresas no Brasil. Doctoral Thesis. Belo Horizonte: UFMG. http://www.cedeplar.ufmg.br/ economia/teses/2008/Luciano_Povoa.pdf [Accessed September, 21 2009]. 
PÓVOA, L. M.C.(2010). A universidade deve patentear suas invenções? Revista Brasileira de Inovação, 9(2), 23I-256.

QUERIDO, A.L.S., Lage, C.L.S., Vasconcellos, A.G. (20II) What is the Destiny of Patents of Brazilian Universities? Journal ofTechnologyManagement\&Innovation.6(I),46-57.

SÁBATO, J.A., Botana, N. (1975) La ciencia y la tecnología en el desarrollo futuro de América latina. In: Sabato, J. A. El pensamiento latinoamericano em la problemática: ciencia, tecnología, desarrollo e dependencia. Buenos Aires: Paidós.

SHANE, S., Somaya, D. (2007) The effects of patent litigation on university licensing efforts. Journal of Economic Behavior \& Organization. 63(4) 739-755.

SIEGEL, D.S., Waldman, D.A., Atwater, L.E., Link, A.N. (2003) Commercial knowledge transfers from universities to firms: improving the effectiveness of university-industry collaboration. Journal of High Technology Management Research. I4(I), III-I33.

SIEGEL, D.S., Waldman, D.A., Atwater, L.E., Link, A.N. (2004) Toward a model of the effective transfer of scientific knowledge from academicians to practitioners: qualitative evidence from the commercialization of university technologies. Journal of Engineering and Technology Management. 2I(I-2), II5-I42.

SIEGEL, D.S., Veugelers, R., Wright, M. (2007) Technology transfer offices and commercialization of university intellectual property: performance and policy implications. Oxford Review of Economic Policy, 23(4), 640-660.

SPITHOVEN, A., Clarysse, B., Knockaert, M. (2010) Building absorptive capacity to organise inbound open innovation in traditional industries. Technovation, 30(2), $|30-| 4 \mid$.

THURSBY, J.G., Thursby, M.C. (2007) University licensing. Oxford Review of Economic Policy, 23(4), 620-639.

TÖDTLING, F., Lehner, P., Kaufmann, A. (2009) Do different types of innovation rely on specific kinds of knowledge interactions? Technovation, 29(I), 59-7I.
WINTER, S. (1988) On Coase, Competence, and the Corporation. The Journal of Law, Economics \& Organization. 4(I), 163-180.

YIN, R. K. (2003) Estudo de caso: planejamento e métodos. 2 e.d. Porto Alegre: Bookman.

ZAWISLAK, P.A. (1995) Relação entre Conhecimento e Desenvolvimento: essência do progresso técnico. Análise, Porto Alegre, 6(I), I25-149. 
J. Technol. Manag. Innov. 20I I,Volume 6, Issue 3 